\title{
Incidence of malaria and salmonellosis co-infection in Ahmadu Bello University Teaching Hospital, Zaria, North-West Nigeria
}

\author{
Igiri BE ${ }^{1,2 *}$, Ejezie CG${ }^{1}$, Inyang-Etoh $\mathrm{PC}^{1}$, Jimoh $\mathrm{O}^{3}$, Okoduwa $\mathrm{SIR}^{2}$, Otu-Bassey IB ${ }^{1}$ and Ogba OM${ }^{1}$ \\ ${ }^{1}$ Department of Medical Laboratory Science, University of Calabar, Nigeria \\ ${ }^{2}$ Directorate of Research and Development, Nigerian Institute of Leather and Science Technology, Nigeria \\ ${ }^{3}$ Department of Medical Microbiology, Ahmadu Bello University Teaching Hospital, Nigeria
}

\begin{abstract}
Malaria and enteric fever infection co-exists in tropical region of the biosphere due to prevailing climatic conditions and poor hygiene practice. This work is aimed at determining the incidence of malaria-typhoid co-infection among patients in Ahmadu Bello University Teaching Hospital Zaria, Kaduna State, Nigeria. Patients' bio-data were obtained through structured questionnaire and diagnosis was done using venous blood sample obtained from the participants. Blood smear was used for analysis of malaria parasites while widal test and blood culture was used for the analysis of enteric fever. The temperature of the respondents was $\geq 38$ c. Of the 216 patients enrolled for the study (141 females and 75 males), 49 (22.7\%) had malaria and typhoid fever co-infection using Widal test, and none (0.0\%) was positive for typhoid fever using blood culture. The prevalence of Malaria-typhoid co-infection was highest among those in the age group $>60$ years (66.7\%), those into tertiary education (30\%), the Yoruba ethnic group (25\%), those in the weight group 41-50 (40\%), the employed (24\%) and those who are married (30\%). A substantial association exist in the malaria-typhoid fever co-infection between the age groups at $\left(x^{2}=3.06, p>0.05\right)$. There was a statistical relationship between malaria and typhoid fever at $(\mathrm{r}=0.967, p>0.05)$. Therefore, blood culture should be adopted as a decisive diagnosis for typhoid fever in order to remarkably reduce the assumingly high prevalence of typhoid and its co-infection with malaria and to avoid the indiscriminate use of antibiotics without laboratory confirmation.
\end{abstract}

\section{Introduction}

Malaria is a life threatening protozoan illness of human and monkeys. In the ecosphere today, about $80 \%$ of these cases and $90 \%$ of deaths cause by malaria arises in the sub-Sahara Africa [1-4]. Globally, Nigeria accounts for about $50 \%$ of malaria deaths $[5,6]$. Malaria has social consequences and exerts heavy burden on economic development [7,8]. About 3.3 billion individuals worldwide remain at danger of malaria in addition to emerging ailment [9]. Clinical diagnosis of malaria is based on the patient's signs and symptoms at physical examination $[9,10]$.

Pregnant women are more susceptible to attacks of malaria and develop antibodies and become semi-immune which is being suppressed particularly by Plasmodium falciparum [11,12]. In spite of all effort by government, WHO and non-governmental organization, malaria parasites are endemic in the tropical district [13]. Malaria account for $60 \%$ of outpatient visits, $30 \%$ of hospitalizations, $30 \%$ of children below 5 years mortalities, $25 \%$ infants deaths and $11 \%$ maternal deaths [14-16].

Typhoid fever is a major public health concern in tropical developing countries, especially in areas where access to clean water and other sanitation measures are limited [17-19]. Salmonella typhi is the etiologic agent of man illness like typhoid fever, gastroenteritis and bacteria in the blood $[20,21]$. Growth period of Salmonella typhi is from 3 to 60 days, and signs are usually obtainable from 1 to 14 days of infection [22].

Malaria and typhoid fever are ailments of community health concern in the sub-Sahara area of the biosphere with similar clinical symptoms and fever being the foremost medical presentation [23]. According to Ohanuet al. [24], these infectious diseases are common in Nigeria like other tropical and sub-Sahara Africa areas of the ecosphere. In view of this, people in Nigeria are at high risk of infections of both malaria and typhoid fever either at the same time or as an acute infection [25]. Malaria and typhoid fever share clinically related symptoms, but malaria causes difficult fever than typhoid fever [26]. This study was carried out to determine the prevalence co-infection of malaria and typhoid fever infections among patients with febrile illness. The study also aimed at determining the reliability of Widal test and blood culture in the diagnosis of typhoid fever.

\section{Materials and methods}

\section{Study area}

The study was carried out in Ahmadu Bello University Teaching Hospital, Zaria of Kaduna state, North West Nigeria. The coordinates are along latitude $10^{\circ}, 20$ ' $\mathrm{N}$ and longitude $7^{\circ}, 45^{\prime} \mathrm{E}$. The state shares boundaries with Niger State to the west, Zamfara, Kastina and Kano states to the north, Bauchi and Plateau States to the east and FCT Abuja

Correspondence to: Igiri BE, Department of Medical Laboratory Science, University of Calabar, Calabar, 540281, Nigeria, Tel: +234-7068597797, E-mail: egwubernard2@gmail.com

Key words: co-infection, malaria, typhoid fever, blood culture, widal test

Received: March 12, 2018; Accepted: April 18, 2018; Published: April 23, 2018 
and Nassarawa State to the south.

\section{Study design}

It was a cross-sectional hospital-based study that was used to determine the co-infection of malaria and typhoid fever in Ahmadu Bello University Teaching Hospital, Zaria, Kaduna State.

\section{Target population}

All patients attending General Out Patients Department of ABUTH with febrile illness were enrolled for the study.

\section{Inclusion criteria}

Patients of both sexes and all age groups with febrile illness attending Ahmadu Bello University Teaching Hospital, Zaria, Northwest, Nigeria were enrolled in the study.

\section{Exclusion criteria}

Patients with catheterization done within 6 days before the study were excluded.

\section{Ethical clearance}

Ethical approval for this work was gotten from the Health Research Ethics Committee of Ahmadu Bello University Teaching Hospital (ABUTH) Zaria, North-west, Nigeria (Protocol number: ABUTHZ/ HREC/U10/2016).

\section{Informed consent}

Written informed consent was sought from participants/guardian preceding enrolment into the work. Information about the work was described to the participants in English and Hausa languages especially those that could not comprehend English Language. Participation in the study was voluntary and those who declined to take part in the study were still given due attention without any bias.

\section{Sample size}

Precisely 216 participants were used, and the sample size was calculated with a $95 \% \mathrm{CI}$ and precision level of $4 \%$ using the formula by Daniel [27].

$$
\mathrm{n}=\mathrm{z}^{2} \times \mathrm{pq} / \mathrm{d} 2
$$

Where: $\mathrm{n}=$ Sample size

$$
\mathrm{z}=1.96 \text { at } 95 \%
$$$$
\mathrm{P}=\text { Prevalence rate }(10 \%)=0.1[28] \text {. }
$$$$
\mathrm{d}=\text { Sampling error that can be tolerated (0.04) }
$$

\section{Data collection}

Structured questionnaire was given to patients/guardians that gave their permission in order to get information concerning their sociodemographic details, symptoms of the disease and protective measures to prevent infection.

\section{Sampling technique}

A purposive sampling technique was used.

\section{Sample collection}

Blood samples were collected at General Out Patients Department (GOPD) of Ahmadu Bello University Teaching Hospital, Zaria, North- west Nigeria. Two hundred and sixteen blood samples of enrolled patients with fever, headache, vomiting, and fatigue were used for this study. Respondents upper hand were fastened using tourniquet, and cotton wool was soaked in methylated spirit to clean and sterilized the site for blood collection. $5 \mathrm{ml}$ syringe with $21 \mathrm{~g}$ needle was used to withdraw $4 \mathrm{mls}$ of blood from each patient. Dry cotton wood was placed at the site of venipuncture and needle was gently removed while sharps were safely disposed in the sharp box.

Two millilitre $(2 \mathrm{~mL})$ of the blood was aseptically introduced into a culture bottle containing Brain Heart Infusion broth, the remaining 2 mLs of the blood into an Ethylene Diamine Tetra-acetic Acid (EDTA) bottle for malaria parasite determination and allow to settle to obtained serum for serological test.

\section{Diagnosis of malaria parasite}

Thick and thin film stained with Giemsa was prepared for the microscopic examination of the malaria parasite. The thin films were fixed with methanol and all films were stained with $3 \%$ Giemsa stain of pH 7.2 for $45 \min$ [29].

\section{Microscopic examination of blood films}

Blood films were examined microscopically using 100X (oil immersion) objectives as described by [30]. The thick films were used to determine the parasite densities while thin films were used to identify the parasite species and infective stages. For thick films, the ring form, trophozoites and gametocytes was looked for. The presence of Plasmodium species at one per 100 high-power thick fields was considered to be substantial under oil immersion by a train microscopist.

\section{Diagnosis of typhoid fever}

\section{Blood culture}

Two millilitres $(2 \mathrm{ml})$ of the blood samples that was directly inoculated into a culture bottle containing Brain Heart Infusion Broth was incubated at $37^{\circ} \mathrm{C}$ for a period of 7 days. This was sub-cultured on day 3 and 7 on MacConkey agar and Blood agar base (Oxoid) [30,31]. Blood culture media was thrown away as negative after 10 days if no growths occur.

\section{Widal test}

Serological tests were done on all blood specimens by rapid slide titration technique with commercially prepared antigen suspension (Omega diagnostic kit) manufactured by Hill foots business village Alva FK12 5DQ, Scotland, United Kingdom for somatic $(\mathrm{O})$ and flagella $(\mathrm{H})$ antigens [29]. A single drop of each reactant in the direction, paratyphi $\mathrm{A}, \mathrm{B}, \mathrm{C}$ and typhi D of $\mathrm{O}$ antigen and paratyphi $\mathrm{A}, \mathrm{B}, \mathrm{C}$ and typhi $\mathrm{D}$ of $\mathrm{H}$ antigen were placed in the first and second row on white rectangular tile. The serum was obtained from each blood sample using Pasteur's pipette and was added to each reactant and mixed with a stirrer, and the stirrer was dried with cotton wool after each stir. The tile was gently rocked for one minute and was observed for agglutination. A significant titer was considered positive for any serum specimen with antibody titre more than or equal to 1 in 160 for somatic $(\mathrm{O})$ and flagella $(\mathrm{H})$ antibodies.

\section{Statistical analysis}

Data from all the questionnaires was coded, entered and analyzed using statistical package for social science (SPSS), version 23. Result 
of the research findings was subjected to Chi-square test and Pearson correlation coefficient

\section{Results}

A total of two hundred and sixteen (216) patients with febrile illness were enrolled, 75 (34.7 \%) males and 141 (65.3\%) females were examined for malaria and enteric fever co-infection. Of this number, the incidence of malaria and typhoid fever co-existence using Widal test was $22.7 \%$ while none $0.0 \%$ had malaria and typhoid fever coinfection using blood culture techniques (Table 1).

On the malaria-typhoid fever co-infection among participants with respect to age, education and marital status (Table 2), those in the age bracket $>60$ years had a higher incidence of malaria and enteric fever co-infection of $66.7 \%$ while the age group 1-10 years had the least prevalence of $7.9 \%$. There is a significant association between Salmonella co-infection with malaria among the age group $(p>0.05)$. Those in the tertiary had the highest incidence of malaria and typhoid fever co-existence of $30.0 \%$, of which females $24.5 \%$ and males 40.1 $\%$ while the primary had the least $13.6 \%$. The married had $30.0 \%$ incidence of malaria-typhoid fever co-infection compared to single $15.0 \%$ in this study.

However, on the co-infection of malaria and typhoid fever among participants with respect to weights, ethnicity and occupation (Table 3 ), the highest incidence of malaria and enteric fever co-infection 40.0 $\%$ was recorded among 11-20 and 41-50 weight groups while no case of co-infection was recorded among the weight group 21-30 and 91-100. The unemployed had the incidence of $22.0 \%$ compared to the employed

Table 1. Overall prevalence of malaria and typhoid fever co-infection using Giemsa stain, widal test and blood culture respectively.

\begin{tabular}{|c|c|c|c|}
\hline Illness & No. examined & $\begin{array}{c}\text { No. co-infected } \\
\text { using widal (\%) }\end{array}$ & $\begin{array}{c}\text { No. co-infected } \\
\text { using } \\
\text { blood culture (\%) }\end{array}$ \\
\hline $\begin{array}{c}\text { Malaria and Typhoid } \\
\text { Co-infection }\end{array}$ & 216 & $49(22.7)$ & $0.0(0.0)$ \\
\hline
\end{tabular}

Table 2. Malaria-typhoid fever co-infection among participants with respect to age, education and marital status.

\begin{tabular}{|c|c|c|c|c|c|c|}
\hline $\begin{array}{c}\text { Age group } \\
\text { (years) }\end{array}$ & $\begin{array}{c}\text { No. } \\
\text { Examined }\end{array}$ & $\begin{array}{c}\text { No. } \\
\text { Positive } \\
(\%)\end{array}$ & $\begin{array}{c}\text { Male } \\
\text { Examined }\end{array}$ & $\begin{array}{c}\text { Male } \\
\text { Positive } \\
(\mathbf{\%})\end{array}$ & $\begin{array}{c}\text { Female } \\
\text { Examined }\end{array}$ & $\begin{array}{c}\text { Female } \\
\text { Positive } \\
(\mathbf{\%})\end{array}$ \\
\hline $1-10$ & 38 & $3(7.9)$ & 11 & $2(18.2)$ & 27 & $1(3.7)$ \\
\hline $11-20$ & 52 & $9(17.3)$ & 26 & $2(7.7)$ & 26 & $7(26.9)$ \\
\hline $21-30$ & 55 & $18(33)$ & 15 & $5(33.3)$ & 40 & $13(32.5)$ \\
\hline $31-40$ & 38 & $12(32)$ & 10 & $5(50)$ & 28 & $7(25)$ \\
\hline $41-50$ & 18 & $3(16.7)$ & 6 & $1(16.7)$ & 12 & $2(16.7)$ \\
\hline $51-60$ & 9 & $0(0.0)$ & 3 & $0(0.0)$ & 6 & $0(0.0)$ \\
\hline$>60$ & 6 & $4(66.7)$ & 4 & $2(50)$ & 2 & $2(100)$ \\
\hline Total & 216 & $49(22.7)$ & 75 & $17(22.7)$ & 141 & $32(22.7)$ \\
\hline $\mathrm{X}^{2}=3.06$, & $\mathrm{df}=6$, & $p>0.05$ & & & & \\
\hline Education & $\mathrm{X}^{2}=3.95$ & $\mathrm{df}=3$ & $p>0.05$ & & & \\
\hline Nonformal & 36 & $9(25)$ & 10 & $1(10)$ & 26 & $8(30.7)$ \\
\hline Primary & 44 & $6(13.6)$ & 16 & $3(18.8)$ & 28 & $3(10.7)$ \\
\hline Secondary & 65 & $13(20)$ & 27 & $4(14.8)$ & 38 & $9(23.7)$ \\
\hline Tertiary & 71 & $21(30)$ & 22 & $9(40.1)$ & 49 & $12(24.5)$ \\
\hline Total & 216 & $49(23)$ & 75 & $17(22.7)$ & 141 & $32(22.7)$ \\
\hline Marital & $\mathrm{X}^{2}=0.07$ & $\mathrm{df}=1$ & $p>0.05$ & & & \\
\hline Status & 110 & $33(30)$ & 29 & $11(37.9)$ & 81 & $22(27.1$ \\
\hline Married & 106 & $16(15)$ & 46 & $6(13.0)$ & 60 & $10(16.7)$ \\
\hline Single & 216 & $49(22.7)$ & 75 & $17(22.7)$ & 141 & $32(22.7)$ \\
\hline Total & & & & & & \\
\hline
\end{tabular}

Table 3. Co-infection of malaria and typhoid fever among participants with respect to weights, ethnicity and occupation.

\begin{tabular}{|c|c|c|c|c|c|c|}
\hline Weights & $\begin{array}{c}\text { No. } \\
\text { Examined }\end{array}$ & $\begin{array}{c}\text { No. } \\
\text { Positive } \\
(\%)\end{array}$ & $\begin{array}{c}\text { Male } \\
\text { Examined }\end{array}$ & $\begin{array}{c}\text { Male } \\
\text { Positive } \\
(\%)\end{array}$ & $\begin{array}{c}\text { Female } \\
\text { Examined }\end{array}$ & $\begin{array}{c}\text { Female } \\
\text { Positive } \\
(\%)\end{array}$ \\
\hline $11-20$ & 10 & $4(40)$ & 3 & $3(100)$ & 7 & $1(14.3)$ \\
\hline $21-30$ & 36 & $0(0.0)$ & 14 & $0(0.0)$ & 22 & $0(0.0)$ \\
\hline $31-40$ & 25 & $6(24)$ & 12 & $1(8.3)$ & 13 & $5(38.5)$ \\
\hline $41-50$ & 35 & $14(40)$ & 9 & $3(33.3)$ & 26 & $11(42)$ \\
\hline $51-60$ & 42 & $11(26)$ & 19 & $4(21.1)$ & 23 & $7(30.4)$ \\
\hline $60-70$ & 28 & $8(28.6)$ & 10 & $4(40)$ & 18 & $4(22.2)$ \\
\hline $70-80$ & 22 & $3(13.6)$ & 3 & $1(33.3)$ & 19 & $2(10.5)$ \\
\hline $81-90$ & 14 & $3(21.4)$ & 4 & $1(25)$ & 10 & $2(20)$ \\
\hline $91-100$ & 4 & $0(0.0)$ & 1 & $0(0.0)$ & 3 & $0(0.0)$ \\
\hline Ethnicity & $X^{2}=1.47$ & $\mathrm{df}=3$ & $p>0.05$ & & & \\
\hline $\begin{array}{l}\text { Hausa } \\
\text { Fulani }\end{array}$ & 136 & $32(24)$ & 53 & $11(20.8)$ & 83 & $21(25.3)$ \\
\hline Yoruba & 24 & $6(25)$ & 6 & $1(16.7)$ & 18 & $5(27.8)$ \\
\hline Igbo & 7 & $0(0.0)$ & 1 & $0(0.0)$ & 6 & $0(0.0)$ \\
\hline Others & 49 & $11(22)$ & 15 & $5(33.3)$ & 34 & $6(17.6)$ \\
\hline Total & 216 & $49(23)$ & 75 & $17(22.7)$ & 141 & $32(22.7)$ \\
\hline Occupation & $\mathrm{X}^{2}=8.94$ & $\mathrm{df}=1$ & $p>0.05$ & & & \\
\hline Employed & 75 & $18(24)$ & 31 & $11(35.5)$ & 44 & $7(15.9)$ \\
\hline Unemployed & 141 & $31(22)$ & 44 & $6(13.6)$ & 97 & $25(25.8)$ \\
\hline Total & 216 & $49(23)$ & 75 & $17(22.7)$ & 141 & $32(22.7)$ \\
\hline
\end{tabular}

$\mathrm{X}^{2}=5.62, \mathrm{df}=8, p>0.05$

$24 \%$. Also, the Yoruba ethnic group had higher incidence of malaria and typhoid fever co-infection $25.0 \%$ than other tribes (Table 3).

The participants' attitude towards medication before laboratory diagnosis (Figure 1) showed that $29.6 \%$ took antimalarial drugs before the laboratory test, $7.4 \%$ took antibiotics while $10.6 \%$ took both antimalarial and antibiotics. It was also found that $52.3 \% \mathrm{did}$ not take either antimalarial or antibiotic drugs. $19.0 \%$ of the respondents reported that the drugs were prescribe and administered to them by doctor, $7.8 \%$ by nurse, $3.2 \%$ by laboratory scientist, $4.2 \%$ by pharmacist and $13.4 \%$ was self-medication (Figure 1 ).

\section{Discussion}

The co-existence of malaria and typhoid fever is of significant public health challenge in Zaria, Kaduna State, Nigeria. These infectious diseases are ranked among the most frequent causes of morbidity and mortality especially among children $[32,33]$. In developed countries of the world, the incidence of cases and death of malaria and typhoid fever has drastically diminish due to a combination of better-quality sanitation and hygiene, vaccine, anti-malarial and antibiotic chemotherapy and effective vector control.

In this study, fortynine $(22.7 \%)$ had co-infection of malaria and typhoid fever using Widal test (Table 1). The observed prevalence rate of malaria-typhoid fever co-infection was similar to the results obtained by previous investigators in other parts of the country and neighboring countries [34,35]. Opara et al. [34] and Ukagaet al. [35] reported $22 \%$ and $20 \%$ respectively in Owerri. This high incidence could be attributed to haemolytic anaemia and malaria parasites specific factors which raise the patients' vulnerability to non-typhoidal Salmonella serotypes (NTS) as reported by Mbuh et al. [36]. This could also be due to the fact that study was carried out during raining season alone (July to October) when infection rate was high. However, Nwuzoet al. [37], Samathaet al. [38], and Mbuh et al. [36] recorded low prevalence rate of $5.6 \%, 6.5 \%$, and $10.1 \%$ in Enugu, Guntur and Zaria respectively. Also, the result of Salmonella co-infection with malaria was $0.0 \%$ using blood 


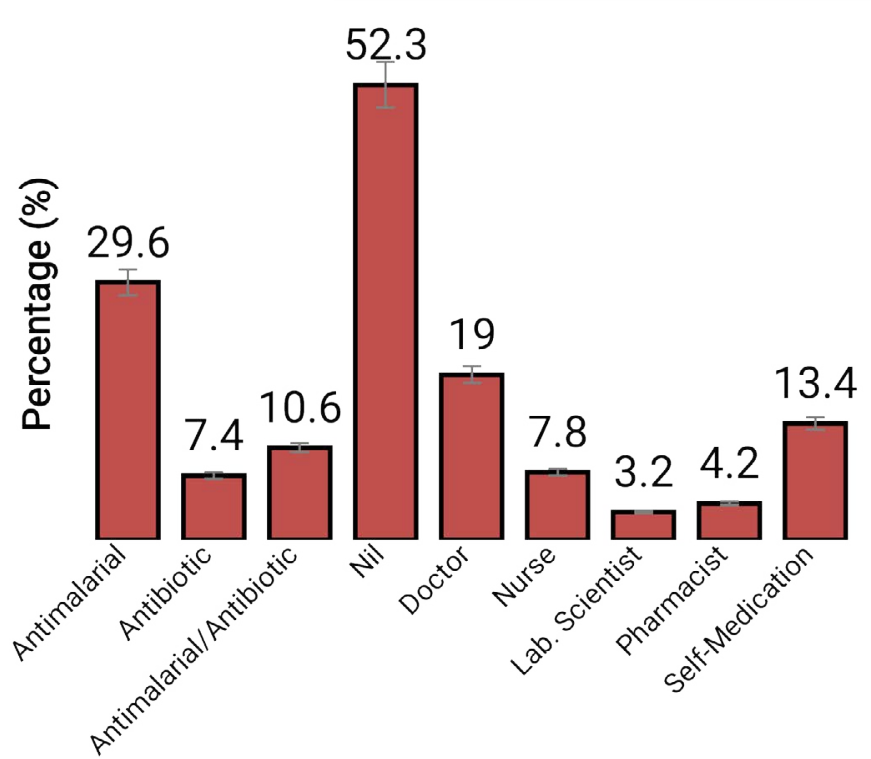

Figure 1. Participants attitude towards medication before laboratory diagnosis in the study area.

culture (Table 1) is in agreement with earlier reports by Mbuhet al. [36], Samathaet al.[38], Oroket al. [39], Sundufuet al. [40], and Nwuzoet al. [37], that reported $0.5 \%, 0.7 \%, 0.8 \%, 0.6 \%$ and $0.8 \%$ in Zaria, Guntur, Calabar, Sirra Leone and Abakaliki respectively. However, this result is in contrast with the finding of Akinyemi et al. [41] and Ohanuet al. [24] that recorded $19.95 \%$ and $26.6 \%$ in Lagos and Enugu respectively. The disparity could be as a result of environmental friendly and climatic variance in many parts of the country, poor hygiene and lack of potable water. This low prevalence rate $(0.0 \%)$ obtained using blood culture could be due to the volume of blood collected or the use of antibiotics by patients prior to the time of the test.

In this study, $66.7 \%, 30 \%$, and $30 \%$ of age group greater than 60 years, tertiary and married participants respectively had the highest prevalence of Salmonella co-infection with malaria (Table 2). Also, the weight group 11-20 and 41-50 had 40\% prevalence with no infection among the weight group 21-30 and 91-100 (Table 3). The high prevalence rate could probably be attributed to more exposure to contaminated water and malaria parasite due to bad environmental conditions. Crossreactions with other antigens as well as those from non-typhoidal Salmonella and malaria antigens can occur as a consequence of latent and post-infectious diseases widespread in the tropics like amoebiasis, tuberculosis, pneumonia, rickettsia diseases, rheumatoid arthritis and chronic active hepatitis [42]. Complement components like Clq and C4 deficiency are associated with Salmonella co-infection with malaria. Complement activation during malaria consumed complement components and impaired the host defense [43]. It is a common habit among patients in Zaria to receive malaria and typhoid fever treatment instantaneously before laboratory analysis or rely on the cheaper and quick Widal test for the diagnosis of typhoid fever.

\section{Conclusion}

This study observed an antigenic cross reaction between malaria parasites and other Salmonella species in the blood which could be the reason for the much talk of malaria and typhoid fever co-infection in Zaria, Kaduna State. The use of blood culture techniques should be advocated in the diagnosis of typhoid fever. This will greatly diminish the high prevalence of malaria-typhoid co-infection in Nigeria and other malaria endemic areas of the world. The prevalence of malaria among the participants was high in spite of various control measures. Hence, there is need to strengthen and scale up various malaria control programs.

\section{Acknowledgments}

This research did not receive any specific grant from funding agencies in the public, commercial, or not-for-profit sectors. The authors are grateful to the management and staff of ABUTH for granting us access to use their facilities for the study. We are highly indebted to the staff at Medical Microbiology Department of ABUTH, especially Dr A. Ibrahim, Mr. Theophilus C. Mbah, the Chief Medical Laboratory Scientist, Medical Microbiology ABUTH, Mr. Iliya Kigbu and Mallam Musa for their technical supports in making this project a reality.

\section{Author Contributions}

Author B.E.I. got the concept and design of the study. Authors G.C.E., P.C.I, and O.J. participated in the revision of the work. Authors S.I.R.O., I.B.O. and O.M.O. carried out the statistical analysis and the data interpretation. Author S.I.R.O. managed the literature searches and critical review of the manuscript for important intellectual content. The final version for publication was written by B.E.I. All the authors read and approved the final version for publication.

\section{References}

1. Caraballo H, King K (2014) Emergency department management of mosquito-borne illness: Malaria, dengue, and west nile virus. Emerg Med Pract 16:1-23. [Crossref]

2. Iheukwumere I, Nwachukwu, Chuks N, Kannu, Mercy A (2013) Manifestations, mismanagement and diagnostic challenges of malaria and typhoid fever. Malaria Chem Contr Elim 2: 38-41.

3. Ekesiobi AO, Igbodika MC, Njoku OO (2008) Co-infection of malaria and typhoid fever in a tropical community. Animal Research International 5: 888-891.

4. Uneke CJ (2008) Concurrent malaria and typhoid fever in the tropics: The diagnostic challenges and public health implications. J Vector Borne Dis 45: 133-142. [Crossref]

5. World Health Organization. Malaria (2017) Geneva: World Health Organization [Online] Available from: http://www.who.int/ mediacentre/factsheets/fs094/en/ [Accessed on 1st July, 2017]

6. Okpe O, Habila N, Ikwebe J1, Upev VA, Okoduwa SIR, et al. (2016) Antimalaria Potential of Carica papaya and Vernonia amygdalina in Mice Infected with Plasmodium berghei. J Trop Med 2016: 8738972. [Crossref]

7. Nkumama IN, Meara WP, Osier FH (2017) Changes in malaria epidemiology in Africa and new challenges for elimination. Trends Parasitology 3: 128-140.

8. Ukoli FMA (1992) Prevention and control of parasitic diseases in Tropical Africa Ibadan: University Press Plc. 45-67.

9. World Health Organization (2015) Malaria Fact Sheet No 94. World Health Organization Geneva 27, Switzerland.

10. CDC (2016) The History of Malaria, an Ancient Disease. Division of Parasitic Diseases and Malaria. USA.

11. Bardají A, Martínez-Espinosa FE, Arevalo-Herrera M, Padilla N, Kochar S, et al. (2017) Burden and impact of Plasmodium vivax in pregnancy: a multi-centre prospective observational study. PLoS Negl Trop Dis 11: e0005606. [Crossref]

12. Stephens JK, Kyei-Baafour E, Dickson EK, Ofori JK, Ofori MF, et al. (2017) Effect of IPTp on Plasmodium falciparum antibody levels among pregnant women and their babies in a sub-urban coastal area in Ghana. Malar J 16: 224. [Crossref]

13. Akanbi OM, Omonkhua AA, Cyril-Olutayo MC (2014) Effect of methanolic extract of stem bark of Anogeissusleiocarpus on liver function of mice infected with Plasmodium berghei. Journal Herbs Species Medicinal Plants 20: 350-358.

14. Rupashree S, Jamila M, Sanjay S, Ukatu VE (2014) Knowledge, Attitude and practices on malaria among the rural communities in Aliero, Northern Nigeria. J Family Med Prim Care 3: 9-44. [Crossref] 
15. Noland GS, Graves PM, Sallau A, Eigege A, Emukah E, et al. (2014) Malaria prevalence, anaemia and baseline intervention coverage prior to net distribution in Abia and Plateau States, Nigeria. BMC Infect Dis 14:168. [Crossref]

16. National Population Commission (NPC) (Nigeria) (2009) ICF Macro: Nigeria Demographic and Health Survey 2008"Abuja, Nigeria: NPC and ICF Macro. Centre for Disease Control and Prevention (2009). Typhoid fever (online) Available http://www.cdc.gov/ncidod/dbmd/.

17. Mutua JM, Wang FB, Vaidya NK (2015) Modelling malaria and typhoid fever coinfection dynamics. Math Biosci 264: 128-44. [Crossref]

18. Pitzer VE, Feasey NA, Msefula C, Mallewa J, Kennedy N, et al. (2015) Mathematical modelling to assess the drivers of the recent emergence of typhoid fever in Blantyre, Malawi. Clin Infect Dis 61: S251-258. [Crossref]

19. Crump J A, Mintz ED (2010) Global trends in typhoid and paratyphoid fever. Clin Infect Dis 50: 241-246. [Crossref]

20. Wain J, Hendriksen RS, Mikoleit ML, Keddy KH, Ochiai RL (2015) Typhoid fever. Lancet 385: 1136-1145. [Crossref]

21. Callaway TR, Edrington TS, Anderson RC, Byrd JA, Nisbet DJ (2008) Gastrointestina microbial ecology and the safety of our food supply as related to Salmonella. J Anim Sci 86: E163-172. [Crossref]

22. Chatterjee A, Varman M, C.'Keefe O (2016) Pediatric Salmonella Infection Clinica Presentation. Medscape.

23. Igharo EA, Osazuwa F, Ajayi SA, Ebuck A, Igbinigie O (2012) Dual infection with typhoid and malaria in febrile patients in Ikara Akoko, Nigeria. International Journal of Tropical Medicine 7: 49-52.

24. Ohanu MF, Mbuh AU, Okonkwo PO, Nwagbo FS (2003) Interfernce with malaria in the diagnosis of typoid using Widal test alone. West Afr J Med 22: 250-252. [Crossref]

25. Keong BCM, Sulaiman W (2006) Typhoid and malaria co-infection an interesting finding in the investigation of tropical fever. Malays J Med Sci 13: 74-75. [Crossref]

26. Igbeneghu C, Olisekodiaka MJ, Onuegbu JA (2009) Malaria and typhoid fever among adult patients presenting with fever in Ibadan, Southwest Nigeria. International Journal of Tropical Medicine 4: 112-115.

27. Daniel WW (1999) Biostatistics: A foundation for Analysis in the Health Sciences. (7th edn). New York, John Wiley and Sons: USA.

28. Alhassan, Shidali HM, Manga NN, Abdullahi SB, Hamid KM (2012) Co-infection profile of Salmonella typhi and malaria parasites in Sokoto-Nigeria. Global Journal of Science, Engineering and Technology 2: 13-20.

29. Cheesebrough, M (2006) District Laboratory Practice in Tropical Countries Part 1. $\left(2^{\text {nd }}\right.$ Edn), Cambridge, Cambridge University Press: UK.
30. Cheesbrough, M (2002) District Laboratory Practice in Tropical Countries Part 2. Cambridge University Press: 182-186.

31. Duguid JP, Marmion BP, Swain RH (1984) Medical Microbiology; a Guide to the Laboratory Diagnosis and Control of infection. J Clin Pathol 1: 315-316.

32. Greenwood BM, Bojang K, Whitty CJ, Targett GA (2005) Malaria. Lancet 365: $1487-$ 1498. [Crossref]

33. Olasehinde GIO, Ojurongbe AO, Adeyeba OE, Fagade N, Valecha et al, (2014) In vitro studies on the sensitivity pattern of Plasmodium falciparum to anti-malarial drugs and local herbal extracts. Malaria Journal 13: 63. [Crossref]

34. Opera AU, Nnodim JK, Oluwafemi BE, Nwachukwu MI (2011) Co-infection of malaria and typhoid fever among patients in Owerri, Imo State Nigeria. Global Research Journal of Sciences 1: 5-8.

35. Ukaga CN, Orji CN, Orogwu S, Nwoke BEB, Anosike JC et al, (2006) Concomitant bacteria in the blood of malaria patients in Owerri, South Eastern Nigeria. Tanzan Health Res Bull 8: 186-188. [Crossref]

36. Mbuh FA, Gialadima M, Ogbadu L (2003) Rate of co-infection with malaria parasites and Salmonella typhi in Zaria, Kaduna State. Annals of African Medicine 2: 64-67.

37. Nwuzo AC, Onyeagba RA, Iroha IR, Oji AE (2009) Parasitological, bacteriological and cultural determination of prevalence of malaria parasite (Plasmodium falciparum) and typhoid fever co-infection in Abakaliki, Ebonyi State. Scientific Research and Essay 4: 966-971

38. Samatha P, Chalapathi RK, Sowmya SB (2015) Malaria Typhoid Co-infection among Febrile Patients. Journal of Evolution of Medical and Dental Sciences 4:11322-11327.

39. Orok DA, Usang AI, Ikpan OO, Duke EE, Eyo EE, et al. (2016) Prevalence of malaria and typhoid fever co-infection among febrile patients attending College of Health Technology Medical Centre in Calabar, Cross River State, Nigeria. International Journal of Current Microbiology and Applied Sciences 5: 825-835.

40. Sundufu AJ, James MS, Foday IK (2012) Role of co-infection with malaria parasite and Salmonella typhi in Bo city, Southern Sierra Leone. Public Health Research 2: 204-207.

41. Akinyemi KO, Bamiro BS, Coker AO (2007) Salmonellosis in Lagos, Nigeria: incidence of Plasmodium falciparum-associated co-infection, patterns of antimicrobial resistance and emergence of reduced susceptibility to fluoroquinolones. J Health Popul Nutr 25: 351-358. [Crossref]

42. Koeleman JG, Regensburg DF, van Katwijk F, MacLaren DM (1992) Retrospective study to determine the diagnostic value of widal test in non-endemic Country. Eur $J$ Clin Microbiol Infect Dis 11: 167-170. [Crossref]

43. Nyakoe NK, Taylor RP, Makumi JN, Waitumbi JN (2009) Complement consumption in children with Plasmodium falciparum malaria. Malar J 8: 7. [Crossref]

Copyright: (C2018 Igiri BE. This is an open-access article distributed under the terms of the Creative Commons Attribution License, which permits unrestricted use, distribution, and reproduction in any medium, provided the original author and source are credited. 